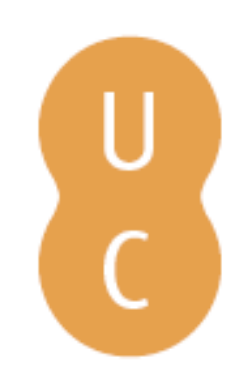

\title{
pombalina
}

\section{Developement of a metodology to assess school bushfire risk}

Autor(es): $\quad \begin{aligned} & \text { Leonard, Justin; Blanchi, Raphaele; Arena, Alessio; Warren, Garth; Opie, } \\ & \text { Kimberley }\end{aligned}$

Publicado por: Imprensa da Universidade de Coimbra

URL

persistente: URI:http://hdl.handle.net/10316.2/44599

DOI: $\quad$ DOI:https://doi.org/10.14195/978-989-26-16-506_82

Accessed : $\quad$ 26-Apr-2023 14:10:44

A navegação consulta e descarregamento dos títulos inseridos nas Bibliotecas Digitais UC Digitalis, UC Pombalina e UC Impactum, pressupõem a aceitação plena e sem reservas dos Termos e Condições de Uso destas Bibliotecas Digitais, disponíveis em https://digitalis.uc.pt/pt-pt/termos.

Conforme exposto nos referidos Termos e Condições de Uso, o descarregamento de títulos de acesso restrito requer uma licença válida de autorização devendo o utilizador aceder ao(s) documento(s) a partir de um endereço de IP da instituição detentora da supramencionada licença.

Ao utilizador é apenas permitido o descarregamento para uso pessoal, pelo que o emprego do(s) título(s) descarregado(s) para outro fim, designadamente comercial, carece de autorização do respetivo autor ou editor da obra.

Na medida em que todas as obras da UC Digitalis se encontram protegidas pelo Código do Direito de Autor e Direitos Conexos e demais legislação aplicável, toda a cópia, parcial ou total, deste documento, nos casos em que é legalmente admitida, deverá conter ou fazer-se acompanhar por este aviso.

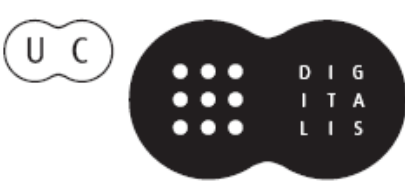




\section{ADVANCES IN}

\section{FOREST FIRE RESEARCH}

\section{8}

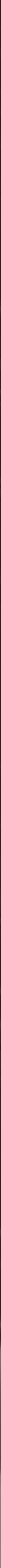




\title{
Developement of a Metodology to Assess School Bushfire Risk
}

\author{
Justin Leonard*; Raphaele Blanchi; Alessio Arena; Garth Warren; Kimberley Opie; \\ CSIRO. Australia. \{justin.leonard@csiro.au*\}
}

\begin{abstract}
This paper describes the methods used to profile the risk posed by forest fire to schools across the state of Victoria, Australia. The methods are principally spatially data driven with augmentation from local assessments and surveys. Schools are assessed in terms of their likelihood of loss from a range of fire arrival severity scenarios and their capacity to effectively provide shelter for school occupants during these events. This is achieved by considering the potential loss of school buildings. The methods also includes an estimate of the radiant heat exposure at assembly areas and egress routes.

As this is now a operational system, the paper describes both the theoretical process and the practical implementation. To address these risk asessements, the schools can implement various risk management processes such as prioritised infrastructure upgrades, vegetation management programs, pre-emptive temporary relocation, targeted education and training. These risk management strategies are considered and developed according to the risk profile of the individual school.
\end{abstract}

Keywords: Wildland, wildfire, forest, fire, bushfire, risk assessment, WUI, warnings, policy

\section{Introduction}

Wildfires or bushfires pose a danger to life and property in Australia. This risk requires active management by relevant State governments, who manage education in Australia. Hence, schools in bushfire prone areas are required to incorporate bushfire risk in their emergency management plans (EMP), which may include forced closures on days which exceed certain fire weather severity thresholds. The EMP is developed by the school with support from government and the regional fire Authority. These plans include relocation triggers, egress paths, facility management and the identification of a shelter-in-place (SIP) building. The SIP building is used as the primary emergency shelter when students and staff are on-site during a bushfire event and it is too late to safely evacuate. A SIP building may be a designated building, or one or more designated rooms within a building. EMP's also consider outside Assembly Areas (AA), as a contingency in the event that the primary shelter is compromised.

This paper presents an evidence based methodology that has been developed to identify schools at highest risk from forest fire and to quantify the risk to school assets (i.e. school buildings and grounds) and their occupants. The methodology is based on the potential for bushfire to impact school buildings and the schools' Assembly Area(s). Risk is based on modelling which uses a combination of landscape factors, including the local terrain, proximity to bushfire fuel, and the type of forest fuel. The primary output of this work is a standardised risk profile of schools, which is used to set appropriate relocation triggers and to prioritise mitigation strategies.

\section{Defining the hazard}

Bushfires can harm people and damage property through flame attack, radiant heat exposure, ember attack, wind attack, hazard and convective heat exposure (Ramsay 1987; Blanchi and Leonard 2008; Leonard and Blanchi 2012). Among these impact mechanisms, flame attack, radiant heat exposure and ember attack are the most relevant when assessing hazard to life and structures (Leonard and Blanchi 2012). The exception is when certain individuals are susceptible to smoke exposure, in which case specific mitigation measures are required.

Advances in Forest Fire Research 2018 - Page 750 
The preferred metric for estimating bushfire hazard at the landscape scale is fire line intensity (for radiant heat and flame exposure) and bark hazard (for ember attack) (Harris et al., 2012; Kilinc et al., 2014). A combination of these metrics is used to quantify hazard to buildings. Radiant heat is used as a proxy to quantify safe distance for people outside of buildings, in terms of direct radiant heat damage, as well as smoke and ember exposure.

People typically seek shelter when exposed to the radiant heat and smoke of a bushfire. Research have highlighted the importance of contingency planning, and of active sheltering and situation monitoring (Blanchi et al., 2018; Whittaker et al., 2017). Research also indicates that safe sheltering requires appropriately designed and situated shelters. Sheltering inside a building offers the most protection against the effects of fire when it is too late to evacuate safely. This raises the additional questions of when to exit the shelter, where to go, and what is the best path to take. The risks associated with egress should be properly assessed to reduce the risk to occupants. Further, any AA used as a secondary contingency situated in an open space need to be properly assessed to ensure that they provide sufficient protection.

\section{Risk Profiling methodology}

The methodology defines risk-to-life by considering the severity of a bushfire event, and assessing how vulnerable humans are to that event. Broadly, risk-to-life is considered under two circumstances:

1. When staff and students shelter within the SIP building during the bushfire event.

2. When staff and students leave the SIP building -due to loss of tenability- and move to an exernal AA.

The first circumstance requires an assessment of the likelihood of survival of the SIP building when exposed to a bushfire event. The second circumstance requires an assessment of the risks involved in moving from the SIP building to a designated AA, followed by an assessment of the risk to the AA. These circumstances are linked, given that the second contingency is only required if the SIP building ignites. Timely movement into the SIP, and then (if necessary) from the SIP to the AA is a function of school and SIP design, and the mobility and numbers of student and staff. Survival at the AA is dependent on its design and the ability of staff and students to survive in this environment until support is provided. In each case, it is assumed that suppression support is not available during the event. However, a suppression strategy and assistance through maintained hydrant systems is an important contingency at all school locations.

Factors that contribute to the risk profile of a building include the weather conditions on the day of the fire, the resulting fire exposure, and the buildings design and location (Figure ).

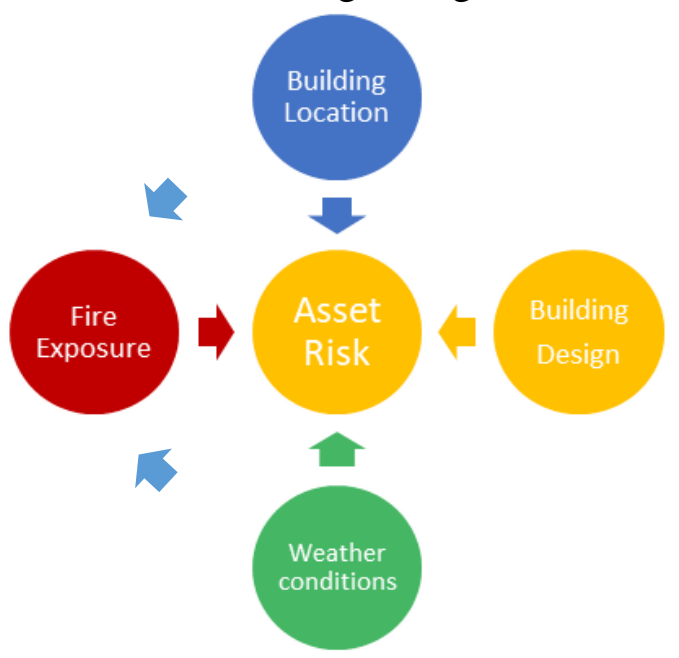

Figure 1 - Factors contributing to asset risk profiles. 
Schools and their constituent buildings are evaluated by first considering the adequacy of the SIP building based on potential building loss (Kilinc et al., 2014), including an exposure risk determined from the surrounding fire line intensity and bark hazard (Leonard et al., 2014; Newnham et al., 2015). In addition, an adjustment of loss is applied based on the buildings compliance and its exposure to other assets. The third step includes a radiant heat estimates of the AA and the egress routes between the SIP and this area.

\section{Assessing building loss potential}

The most relevant empirical analysis of building loss potential for Victoria is described by Kilinc et al. (2014). The authors found that the most important determinants of building loss were fire line intensity, bark hazard and the distance from the building to the forest fuel which supported the bushfire approach (Kilinc et al. 2014). This study was based on a large dataset of past bushfire events which impacted residential buildings with no specific bushfire mitigation measures.

\subsection{Building Loss Potential calculation}

Building Loss Potential (BLP), as described in Kilinc et al. (2014), takes into account the fire line intensity, the distance from the building to the nearest forest, and the bark hazard of any adjacent forest. Note that the definition of forest in this instance is taken from Furby (2002); where a forest is defined as any contiguous patch of vegetation that covers a minimum of 0.2 hectares, with a minimum treecrown-cover of $20 \%$ and a minimum height of 2 meters at maturity. The relationship between these parameters is described using a Generalised Linear Model with a logit link function described in equation 1:

$$
(\boldsymbol{\pi} /(\mathbf{1}-\boldsymbol{\pi}))=\boldsymbol{\eta}=\boldsymbol{\alpha}+\boldsymbol{\beta} \boldsymbol{h}+\boldsymbol{\gamma} \log (\mathrm{FLI})+\boldsymbol{\kappa} \boldsymbol{d}
$$

where $\boldsymbol{F} \boldsymbol{L I}$ is Byram's fire line intensity, $\boldsymbol{d}$ is distance to forest, $\boldsymbol{h}$ denotes bark hazard level, and $\boldsymbol{\alpha}$, $\boldsymbol{\beta}$ and $\boldsymbol{\kappa}$ are the intercept and correlation coefficients respectively. Values for $\boldsymbol{\alpha}, \boldsymbol{\beta}$ and $\boldsymbol{\kappa}$ are presented in Table. These constants hold for all fire intensities excluding those below $3 \mathrm{MW} / \mathrm{m}$ or above 90 $\mathrm{MW} / \mathrm{m}$.

Table 1 - The Estimated coefficients of equation 2 (from Kilinc et al. 2014).

\begin{tabular}{|c|c|c|c|c|c|c|}
\hline $\begin{array}{l}\text { intercept } \\
(\boldsymbol{\alpha})\end{array}$ & $\begin{array}{l}\beta \mathrm{L} \\
\text { (low bark } \\
\text { hazard) }\end{array}$ & $\begin{array}{l}\beta M H \\
\text { (medium-high } \\
\text { bark hazard) }\end{array}$ & $\begin{array}{l}\beta V H \\
\text { (very high } \\
\text { bark hazard) }\end{array}$ & $\begin{array}{l}\beta E \\
\text { (extreme bark } \\
\text { hazard) }\end{array}$ & $\begin{array}{l}\gamma \\
\mathrm{FLI} \text { in } \\
\mathrm{MW} / \mathrm{m}\end{array}$ & $\begin{array}{l}\kappa \\
d \text { in meters }\end{array}$ \\
\hline-5.7295 & 0 & 2.56 & 2.87 & 3.44 & 0.87 & -0.008 \\
\hline
\end{tabular}

The prediction equation (2) for building loss is then:

$$
\hat{\boldsymbol{\pi}}=\mathbf{1} / \mathbf{1}+(-\boldsymbol{\eta})
$$

where $\hat{\boldsymbol{\pi}}$ and $\hat{\boldsymbol{\eta}}$ are estimated values from the fitted model.

\subsubsection{Fire line Intensity}

Fire line intensity is a standardised measure of the rate that an advancing head fire consumes fuel per unit timeand per unit length of fire front (Byram, 1959) and can be calculated as follows:

$$
\boldsymbol{F L I}=\boldsymbol{H} \times \boldsymbol{w} \times \boldsymbol{R}
$$

where $\boldsymbol{F L I}$ is Byram's fire line intensity (usually expressed in kilowatts per linear meter i.e. $\mathrm{kW} / \mathrm{m}$ ), $\boldsymbol{H}$ is the net latent heat of combustion $(\mathrm{kJ} / \mathrm{kg}), w$ is fuel consumed in the active flame front $\left(\mathrm{kg} / \mathrm{m}^{2}\right)$, and $\boldsymbol{R}$ is the linear rate of fire spread $(\mathrm{m} / \mathrm{sec})$. 
One of the main benefits of the fire line intensity metric is that it can be used to estimate potential flame length (Alexander et al., 2012; Byram, 1959) and thus the radiant heat expected at various distances from the flame.

A diverse range of models can be used to determine the rate of spread and fire line intensity, which are generally specific to certain fuel types (Cheney et al., 1995; Gould et al., 2007; McArthur, 1967).

\subsubsection{Bark Hazard}

Research has shown that ember attack accounts for substantially more building loss than either direct flame contact or radiant heat exposure (Leonard et al., 2009). Embers form during a bushfire due to a combination of lofted fine fuels that consist of bark, leaves and fine twigs. These fine fuels exist as deposits on the ground and on the plants themselves, different plant types and plant structures provide different levels of embers.

Bark Hazard, defined in Hines et al. (2010), can be used as a proxy for ember-attack-intensity. Kilinc et al. (2014) confirms this by empirical correlation with house loss potential. Bark hazard relates to its ease of ignition, size, shape, quantity and burning time, and is generally specific to tree species (Hines et al. 2010).

\subsection{Data requirements for BLP calculation}

\subsubsection{Potential Fuel Load}

Potential fuel load is a key driver of fire behaviour, including fire line intensity. The fuel loads used in AS3959 (Standards Australia, 2009) reflect the Australia-wide accepted level for each classification of vegetation; assuming the vegetation has reached its maximum level of fuel accumulation or 'steady state'. For this methodology, fuel loads were sourced either through local field assessments or estimated for broad Ecological Vegetation Classes $(\mathrm{EVCs})^{1}$, used for classifying native vegetation characteristics in its mature and natural state in Victoria.

\subsubsection{Topographic slope}

Topographic slope is an important variable controlling fire spread, the rate of fuel consumption and thus potential fire line intensity. The methodology developed to derive slope is based on the maximum potential slope of the landscape that could influence the rate of fire spread and fire line intensity. Slope is derived from a gridded Digital Elevation Model (DEM) using elevation values at the location and eight neighbouring pixels (Figure).

\begin{tabular}{|c|c|c|}
\hline 1 & 2 & 3 \\
\hline 8 & $x$ & 4 \\
\hline 7 & 6 & 5 \\
\hline
\end{tabular}

Figure 2 - Calculation of landscape slope based on 8 neighbouring values.

Several digital elevation products and derived datasets exist that cover various regions of the study are. For consistence, the methodology used a national gridded DEM derived from the Shuttle Radar Topography Mission (SRTM) at 1 second $(\sim 30 \mathrm{~m})$ resolution.

${ }^{1}$ https://www.data.vic.gov.au/data/dataset (accessed May 2018). 


\subsubsection{Fire Danger Index and fire danger Rating}

Weather conditions play an important role in influencing fire behaviour, the difficulty of suppression and potential to cause damage (Luke and McArthur, 1978). Weather severity is characterised in Australia using a Forest Fire Danger Index (FFDI; McArthur, 1967) or the Grass Fire Danger Index (GFDI), depending on the dominant fuel type. The FFDI relates large-scale weather conditions to the expected fire behaviour, given common forest fuel types in eastern Australia (McArthur, 1967; Luke and McArthur, 1978). The FFDI is a useful metric for characterising the destructive potential of a fire (e.g. Bradstock and Gill, 2001; Blanchi et al., 2010). However, similar studies have not been performed to relate GFDI to similar measures of destructive potential.

In the methodology presented in this report, FFDI forms the basis of the potential fire weather severity inputs, which are used when calculating fire line intensity and bushfire hazard for school assets.

\subsubsection{Bark Hazard classification}

Bark hazard was attributed based on Ecological Vegetation Class (EVC) maps. Bark hazard can also be determined through a field assessment of vegetation if the mapped data provides insufficient information. As shown in Table , BLP considers four categories of bark hazard (taken from Hines et al., 2010). Note that the low bark hazard category poses no risk of ember-attack (bark-hazard constant of zero). Kilinc et al. (2014) found very little difference between the medium and high bark hazard levels, and that combining these categories provides a better overall estimate of BLP.

\subsubsection{Building locations}

The probability that a building will be lost to bushfire increases with fire intensity and decreases with the distance between a building and forest (Kilinc et al., 2014). Kilinc et al. (2014) used building centroids to calculate BLP.

In the proposed methodology, building footprint is defined using site plans of school. The BLP model then considers the distance from each building edge to its nearest area of unmanaged fuel that can support a significant fire line intensity $(>4 \mathrm{MW} / \mathrm{m})$. BLP is then calculated according to this potential fire line intensity. Using potential fire line intensity as a gridded dataset, we can also assess a buildings proximity to high hazard zones.

Finally, buildings that are located more than $500 \mathrm{~m}$ from any potential fire line intensity areas it will be allocated a $0 \%$ probability of loss.

\subsection{BLP workflow}

Figure presents an overview of the BLP workflow. Both the primary inputs and derived layers are shown. The assessments from these two methods can be combined in a number of ways, for example:

- A school is rated according to the better of the two methods. Hence the school's category is defined according to its most effective option out of the two methods (little redundancy in survival options).

- A school is rated according to the weaker of the two methods. Hence the school's category is defined according to its least effective option (high redundancy in survival options).

- A school is rated by the (weighted) average of the two methods. Hence the school's category is defined by averaging the effectiveness of the two methods with an approach weighting factor (some redundancy). 


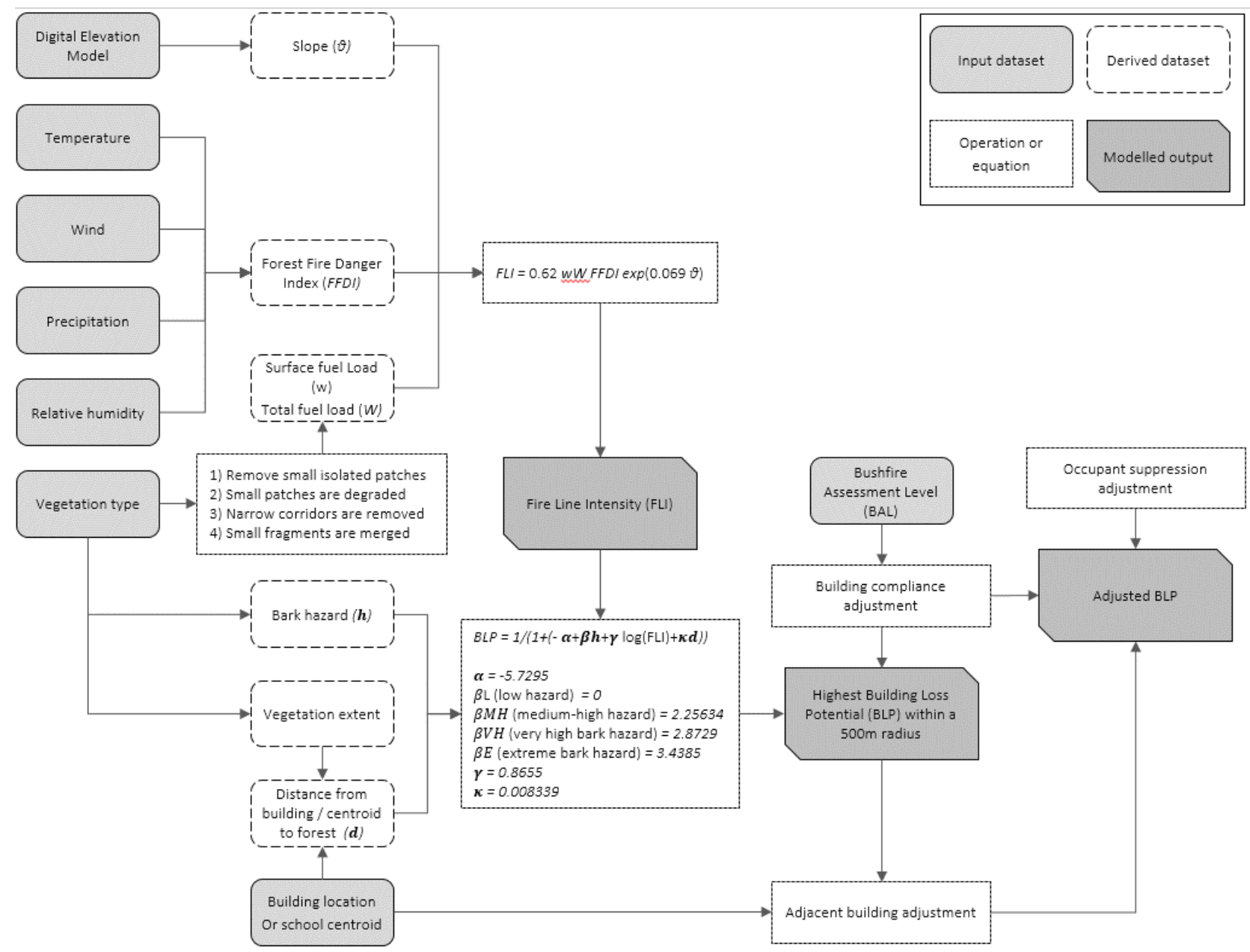

Figure 3 - Overall Building Loss Potential mapping methodology.

\section{Radiation heat exposure assessment of the Assembly Area(s)}

SIP buildings are defined as the primary location of shelter at the school. However, studies on community response have shown the need for contingency planning to account for the risk of shelter failure (Blanchi et al., 2018; Teague et al., 2010). A secondary contingency - Assembly Area (AA) such as an oval could be used as a potential secondary place of shelter either on or off site.

Radiant heat measures can be used to estimate the minimum required separation distances needed to afford safety to people and/or buildings (Cheney et al., 2001; Siggins et al., 2013; Zárate et al., 2008). In Australia, $2 \mathrm{~kW} / \mathrm{m}^{2}$ of radiant heat is often used as the maximum threshold people should sustain in open spaces ${ }^{1}$. Purser and McAllister (2016) stated that radiant heat above $2.5 \mathrm{~kW} / \mathrm{m}^{2}$ causes skin pain, followed by burns within a few seconds. A review of human exposure to radiant heat determined that a level between $4-5 \mathrm{~kW} / \mathrm{m}^{2}$ was the short term threshold beyond which significant injury may occur (Raj, 2008). 
We define the potential risk at the AA by calculating the radiant heat flux received at the location and on the egress path under different weather conditions. We develop a spatial approach to define the minimum distance from various types of vegetation to obtain a maximum tolerable exposure using 5 $\mathrm{kW} / \mathrm{m}^{2}$ as a threshold for short term exposure while moving to an alternate location, and $2.5 \mathrm{~kW} / \mathrm{m}^{2}$ for the alternate shelter location where longer exposure times may occur. The approach take into account the FLI (equation 3) to determine flame length 6 (modified for the effective slope and the vegetation and weather conditions), and then calculate the radiant heat flux based on the StefanBoltzman equation (Sullivan et al., 2003).

\section{Results and discussion}

An example of risk assessment using the methodology decscribe in this paper is presented in this section.

\subsection{BLP assessment}

We sourced information on vegetation type, fuel load, bark hazard and extent from the Ecological Vegetation Classes (EVC) map. The school in this example is located adjacent to forest herb-rich vegetation with a very high bark hazard. The SIP buiding is shown in blue in Figure . Fire line intensity (see Figure ) was then calculated using equation 1, 2 and 3 under a FFDI of 35, 50, 75 and 100, using the EVC derived maps.
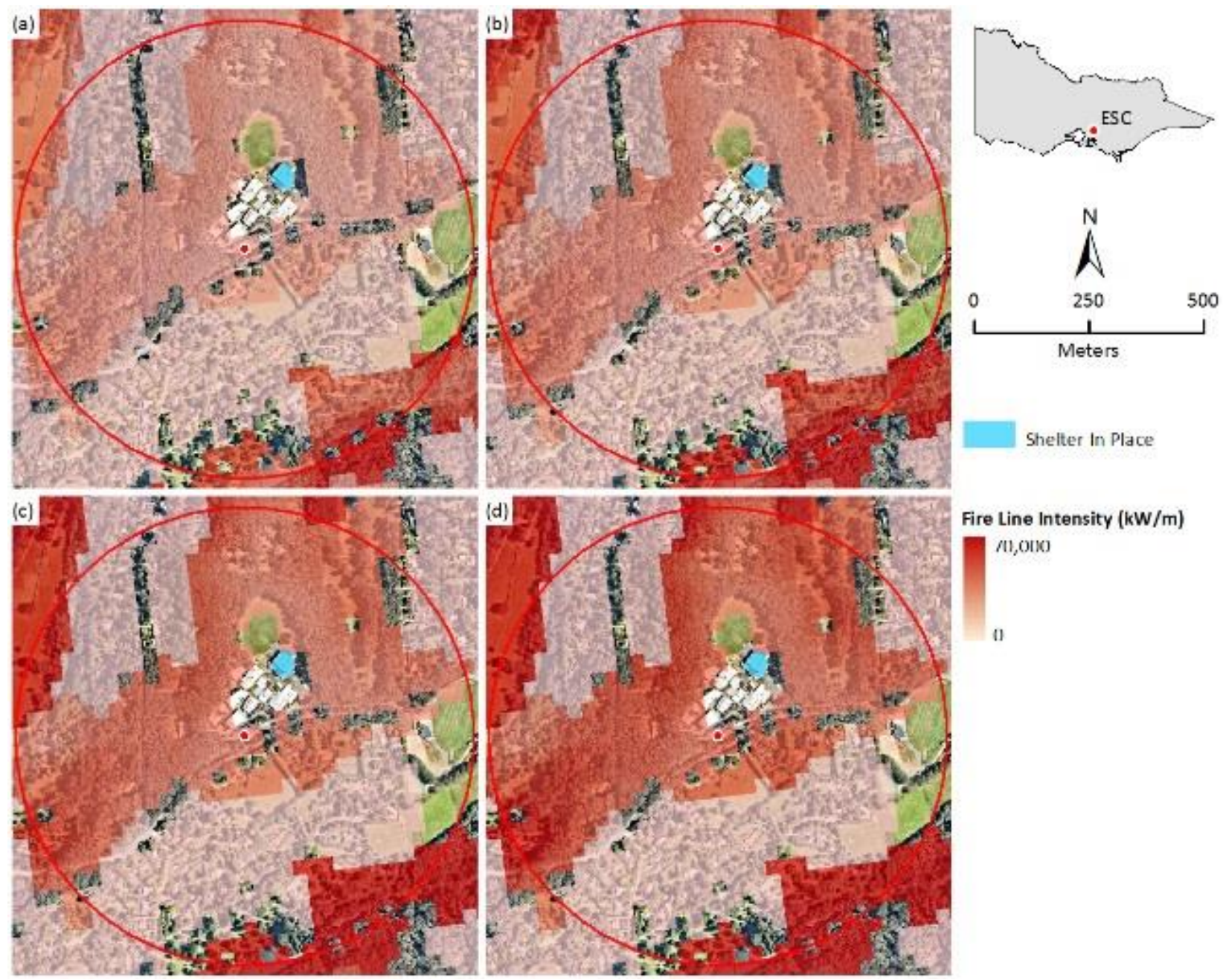

Figure 4 - Fire line intensity in the area surrounding the school SIP building (light blue). Fire Line Intensity for FFDI $35(a), 50(b), 75(c)$, and $100(d)$. 
Table 2 presents the results of BLP at different FFDI, for example BLP is $35 \%$ at a severe FFDI of 75 (Table 2).

Table 2 - Unadjusted Building loss potential at different FFDI.

\begin{tabular}{lllll}
\hline & FFDI 35 & FFDI 50 & FFDI 75 & FFDI 100 \\
\hline BLP at the SIP building & 0.216 & 0.272 & 0.347 & 0.405 \\
\hline
\end{tabular}

\subsection{Radiant Heat Flux Assessement}

The radiant heat flux received at the AA and its associated egress paths were calculated under different weather conditions (FFDI $>50$ and FFDI $>75$ ) to define the minimum distance from various types of vegetation needed in order to obtain the tolerable radiant heat exposure of $5 \mathrm{~kW} / \mathrm{m}^{2}$ and 2.5 $\mathrm{kW} / \mathrm{m}^{2}$.

A contour map of Radiant Heat Flux (RHF) exposures are shown in Figure . In this case, the sport oval adjacent to the SIP building will receive a radiant heat flux exceeding $2.5 \mathrm{~kW} / \mathrm{m}^{2}$ under an FFDI of 50. In order for this to qualify as an AA, fuel managment adjacent to the oval is required in order to reduce the exposure.

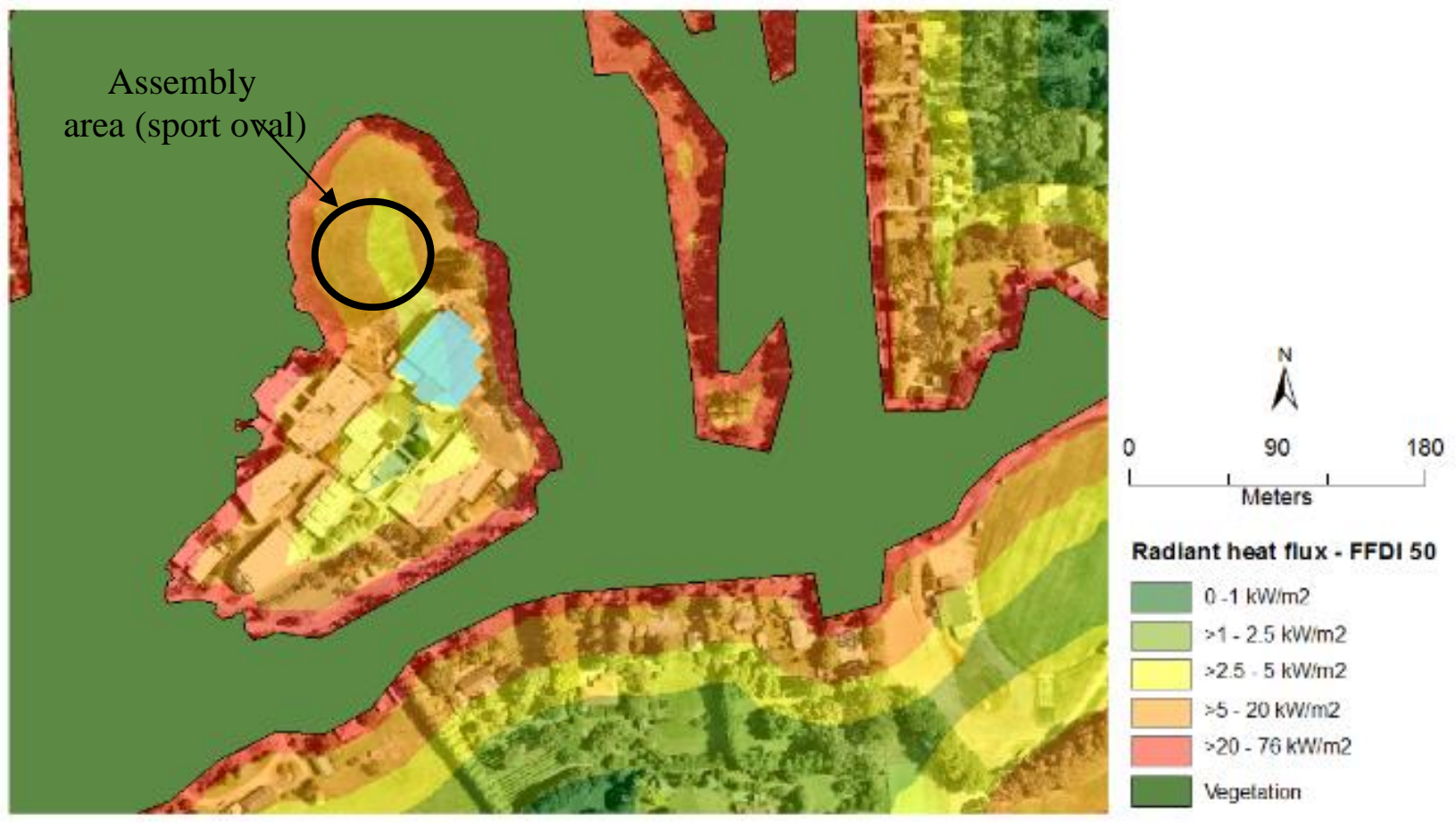

Figure 4 - Radiant heat flux exposure for FFDI 50.

At a FFDI 75 (not shown) all the oval except for a very small central area has a calculated radiant heat exposure greater than $5 \mathrm{~kW} / \mathrm{m}^{2}$. Given the level of exposurethis area is not likely to be a suitable AA for the number of staff and students that may need to utilise this area.

\subsection{Discussion and limitation}

The BLP is designed to be an indicator of hazard for school buildings with no specific bushfire design measures, as per (Kilinc et al., 2014). However, it will require an adjustment for those SIP buildings which have been upgraded using modern building design standards applicable for bushfire prone areas, such as described by AS3959 (Standards Australia, 2009).

The RHF at each location is calculated using the characteristics of the closest fuel. For the RHF calculation, 2.5 and $5 \mathrm{~kW} / \mathrm{m}^{2}$ of radiant heat are the maximum thresholds used in the method, noting 
than $2 \mathrm{~kW} / \mathrm{m}^{2}$ is a conservative medium term exposure level that is also the pain threshold for exposed non-protected skin. In adition, obscuration by buildings vegetation and terrain are not consider when determining maximum radiation levels.

An alternative and more detailed option is to model radiation exposure potential for various fire approach directions, which consider how the terrain, buildings and vegetation obscure radiation heat exposure levels at the AA. These methods can also provide time/radiation profiles which can be a more effective means of setting radiation exposure thresholds (Newnham et al., 2014, 2015).

The present method calculates risk from only forest fuel (McArthur, 1967; Noble, Bary, \& Gill, 1980). Future work will need to consider risk to schools surrounded by grassland or other vegetation types.

\section{Conclusion}

The methodology developed provides an indication of exposure for schools and their occupants. However, in specific bushfire events, risk is extremely difficult to quantify and is dependent on such factors as specific vulnerabilities and impairments of those involved, the capacity for SIP occupants to identify ignitions of the building they shelter in and to suppress them; the rate at which a SIP building may lose tenability; and the rate at which the SIP can be evacuated.

This work has been undertaken with the goal to develop a methodology to objectivly quantify a risk profile for schools. Two discrete methods have been described in this paper to qualify risk at the school level. The first is based on the potential loss of the SIP building, and the second is based on the radiant heat threshold at the AA and along its associated egress paths.

As a response to these assessments, various risk management processes will be considered. These include prioritised infrastructure upgrades, vegetation management programs, pre-empptive temporary relocation under severe weather forecasts, targeted education and training according to the risk profile of the school.

\section{Acknoledgement}

This study was co-funded by the Departement of Education and training Victoria and CSIRO. We would like to thank Wendy Grenville for her contribution and guidance.

\section{Reference}

Alexander, M. E., \& Cruz, M. G. (2012). Interdependencies between flame length and fireline intensity in predicting crown fire initiation and crown scorch height. International Journal of Wildland Fire, 21(2), 95-113. Retrieved from http://www.scopus.com/inward/record.url?eid=2-s2.084858626229\&partnerID=40\&md5=9fc3d3240dd6b7a0073ba5cc469e1a7f

Blanchi, R., Lucas, C., Leonard, J., \& Finkele, K. (2010). Meteorological conditions and wildfirerelated houseloss in Australia. International Journal of Wildland Fire, 19(7), 914-926. Retrieved from http://dx.doi.org/10.1071/WF08175

Blanchi, R., Whittaker, J., Haynes, K., Leonard, J., \& Opie, K. (2018). Surviving bushfire: the role of shelters and sheltering practices during the Black Saturday bushfires. Environmental Science and Policy, 81. Retrieved from https://doi.org/10.1016/j.envsci.2017.12.013

Bradstock, R. A., \& Gill, A. M. (2001). Living with fire and biodiversity at the urban edge: in search of a sustainable solution to the human protection problem in southern Australia. J. Mediterr. Ecol., 2,179 . 
Byram, G. M. (1959). Combustion of forest fuels. in Davis K.P. Byrma G.M. Krumm W.R. Forest fire - Control and use. McGraw-Hill Book Co., New York.

Cheney, N. P., \& Gould, J. S. (1995). Fire Growth in Grassland Fuels. International Journal of Wildland Fire, 5(4), 237-247. Retrieved from http://www.publish.csiro.au/paper/WF9950237

Cheney, P., Gould, J., \& McCaw, L. (2001). The dead-man zone - a neglected area of firefighter safety. Australian Forestry, 64(1), 45-50.

Furby, S. L. (2002). Land Cover Change: Specification for Remote Sensing Analysis. National Carbon Accounting System, Technical Report no. 9.

Gould, J. S., McCaw, W. L., Cheney, N. P., Ellis, P. F., Knight, I. K., \& Sullivan, A. L. (2007). Project Vesta-Fire in Dry Eucalypt Forest: Fuel Structure, Fuel Dynamics and Fire Behaviour. EnsisCSIRO, Canberra, ACT and Department of Environment and Conservation, Perth, WA. Retrieved from http://cbml.csiro.patron.eb20.com/Collections/ViewBookExtended/2b7558ca-863a-44259843-37390fb3c2e3

Harris, S., Anderson, W., Kilinc, M., \& Fogarty, L. (2012). The relationship between fire behaviour measures and community loss: an exploratory analysis for developing a bushfire severity scale. Natural Hazards, 63(2), 391-415. from http://download.springer.com/static/pdf/363/art\%3A10.1007\%2Fs11069-012-0156y.pdf?auth66=1354525465_9a44c03aca914bd1d22eb076b7d76554\&ext=.pdf

Hines, F., Tolhurst, K. G., Wilson, A. A. G., \& McCarthy, G. J. (2010). Overall fuel hazard assessment guide 4th edition. Fire and adaptive management, report no. 82. Victoria: Departement of Sustainability and Environment.

Kilinc, A. M., Anderson, W., \& Anderson, D. (2014). DSE Schedule 5 : Fire Severity Rating project Technical Report 1: Project title: A methodology for state wide mapping of bushfire hazard in Victoria ,.

Leonard, J., Blanchi, R., Leicester, R., Lipkin, F., Newnham, G., Siggins, A., Opie, K., Culvenor, B., Cechet, B., Corby, N., Thomas, C., Habili, N., Jakab, M., Coghlan, R., Lorenzin, G., Campbell, D., \& Barwick, M. (2009). Building and Land use planning research after the 7th February 2009 Victorian bushfires. Preliminary findings. Melbourne: Interim report USP2008/018 - CAF122-212 .

Leonard, J., Opie, K., Newnham, G., \& Blanchi, R. (2014). A new methodology for State - wide mapping of bushfire prone areas in Queensland. Australia.

Luke, R., \& McArthur, A. (1978). Bushfires in Australia. Reprinted with corrections 1986. Canberra Publishing and Printing Co.

McArthur, A. G. (1967). Fire behaviour in eucalypt forests. Leaflet No. 107. Comm. of Australia For. \& Timber Bur.

Newnham, G., Blanchi, R., Leonard, J., Opie, K., \& Siggins, A. (2014). Bushfire Decision Support Toolbox Radiant Heat Flux Modelling: Case Study Three, 2013 Springwood Fire, New South Wales. Melbourne.

Newnham, G., Blanchi, R., Opie, K., Leonard, J., \& Siggins, A. (2015). Incorporating vegetation attenuation in radiant heat flux modelling. International Journal of Wildland Fire, 24(5), 640. Retrieved from http://www.publish.csiro.au/view/journals/dsp_journal_fulltext.cfm?nid=114\&f=WF14090

Newnham, G., Opie, K., Leonard, J., \& Flagship, W. (2015). Mapping Current Bushfire Hazard across the state of Queensland.

Noble, I. R., Bary, G. A. V, \& Gill, A. M. (1980). Mcarthur Fire-Danger Meters Expressed as Equations. Australian Journal of Ecology, 5(2), 201-203. 
Purser, D. A., \& McAllister, J. L. (2016). Assessment of Hazards to Occupants from Smoke, Toxic Gases, and Heat. In Hurley, Gottuk, Hall Jr., Harada, Kuligowski, Puchovsky, Torero, Watts Jr., \& WIECZOREK (Eds.), SFPE Handbook of Fire Protection Engineering (pp. 2308-2428). New York, NY: Springer New York. Retrieved from http://dx.doi.org/10.1007/978-1-4939-2565-0_63

Raj, P. K. (2008). A review of the criteria for people exposure to radiant heat flux from fires. Journal of Hazardous Materials, 159(1), 61-71.

Siggins, A., Newnham, G., Blanchi, R., \& Leonard, J. (2013). A 3 Dimensional ray tracing approach to modelling bushfire radiant heat flux for house using lidar derived vegetation voxel data and quadratic polygonal fire fronts. IEEE International Geoscience and Remote Sensing Symposium. Melbourne, Australia.

Standards Australia. (2009). AS3959 - Construction of buildings in bushfire prone areas. Sydney: Standards Australia. Retrieved from http://www.royalcommission.vic.gov.au/getdoc/2d486ba82cef-45a1-9f3c-6e058ec8a78a/WIT.3000.002.0108.PDF

Sullivan, A. L., Ellis, P. F., \& Knight, I. K. (2003). A review of radiant heat flux models used in bushfire applications. International Journal of Wildland Fire, 12(1), 101. Retrieved from http://www.publish.csiro.au/view/journals/dsp_journal_fulltext.cfm?nid=114\&f=WF02052

Teague, B., McLeod, R., \& Pascoe, S. (2010). 2009 Victorian Bushfires Royal Commission final report: summary. (State Government of Victoria: Melbourne).

Whittaker, J., Blanchi, R., Haynes, K., Leonard, J., \& Opie, K. (2017). Experiences of sheltering during the Black Saturday bushfires: Implications for policy and research. International Journal of Disaster Risk Reduction, 23.

Zárate, L., Arnaldos, J., \& Casal, J. (2008). Establishing safety distances for wildland fires. Fire Safety Journal, 43(8), 565-575. 